\title{
Dr. Reszegi Zsolt*
}

\section{Ejtőernyős ugróruházat lirssz}

\section{Fejvédő, kezeslábas és ugrócipő rendszeresítése a magyar királyi honvéd ejtőernyős századnál}

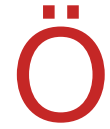

rvendetes dolog, ha a kutatások során eddig nem publikált források bukkannak fel egy bizonyos témával kapcsolatban. Előfordul, hogy ezek az új ismeretek átírják a korábban felkutatott és publikált anyagot, ahogy ez ebben az esetben is történt. ${ }^{1}$

Korábbi kijelentésem - amely szerint kétféle típusú ejtőernyős ugróruha létezett és az őszi-téli változat nem rendelkezett olyan átalakításokkal, mint a tavaszi-nyári kezeslábas ${ }^{2}$ - a most felhasználásra kerülő levéltári iratok segítségével pontosítható.

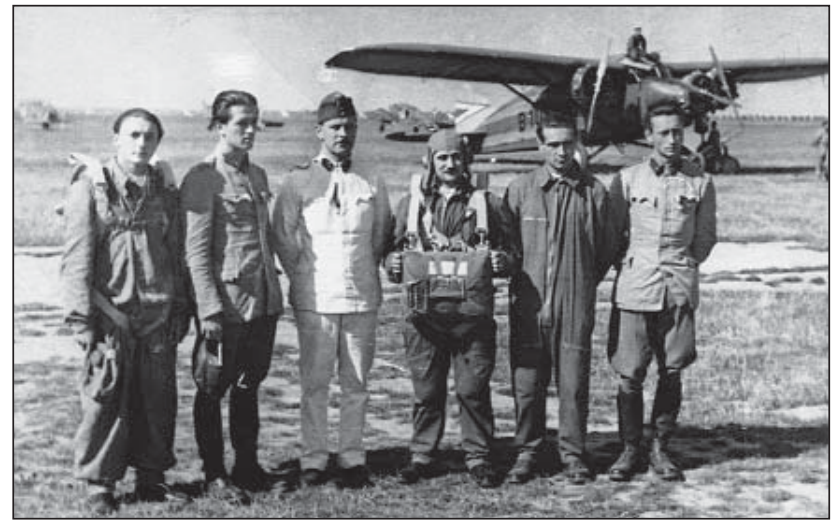

1. ábra. vitéz Bertalan Árpád (balról a harmadik) százados tiszttársaival (Huszár János gyújteménye) ${ }^{3}$

A magyar királyi honvéd ejtőernyős csapatnem ruházata és felszerelése az 1938-1939 közötti időszakban a magyar királyi Honvéd Légierőtől származott.

A légierő hajózó ruházata bőrből készült kezeslábasból állt, amely villámzárral volt ellátva, és kivehető teveszőr béléssel rendelkezett. Téli repülések idején szőrmebéléses csizmát, valamint szőrmés bőrmellényt is adtak hozzá. A nyári hajózó öltözetként drapp ballonvászonból készült

ÖSSZEFOGLALÁS: A magyar királyi honvéd ejtőernyős századnak szüksége volt olyan, speciálisan az ejtőernyősök számára készített, az ugrások során használható ruházatra, amelyet a rendszeresített egyenruhára húzva viselhettek. A meglévő, a hajózó személyzet által használt fejvédő, valamint kezeslábas módositásával gyártották le az 1939M (nyári) ugró fejvédốt, valamint az 1939M egybeszabott ugróruhát. Utóbbi kivehető báránybőr béléssel rendelkezett, ezáltal télen, hidegebb időben is lehetővé vált az ugrások végrehajtása. Az ejtőernyős honvéd ugróruházatát egészítette ki az ejtőernyős ugrócipő.

KULCSSZAVAK: ugróruha, ugró fejvédő, ugrócipő, kezeslábas, gumitalp, szőrmebélés

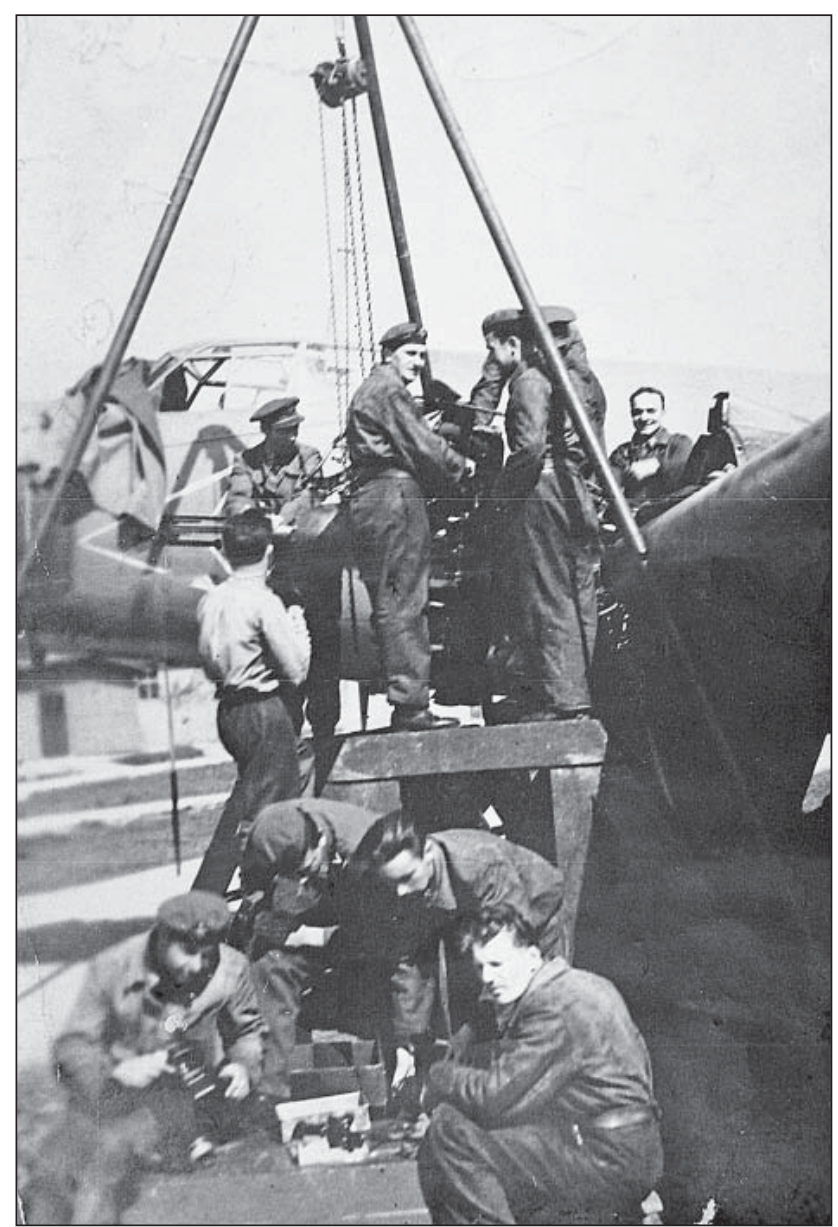

2. ábra. A repülő műszaki század katonái repülögépmotor javítása közben (Huszár János gyứjteménye) ${ }^{5}$

ABSTRACT: The Royal Hungarian Parachute Company needed such clothing, which was specifically made for them, and could be wore over the authorized uniform. The available headgear and smock, used by the pilots of the Royal Hungarian Air Force, was modified, and so was the 1939 M. (summer) jump headgear and the $1939 \mathrm{M}$. customized jumpsuit produced. The latter had a removable liner made of sheepskin, thus the execution of jumps were possible in the cold winter weather. The jump shoes completed the airborne jump suit and headgear.

KEY WORDS: airborne clothing, jump suit, headgear, jump shoe, smock, rubber sole, pelt liner

\footnotetext{
"HM Hadtörténeti Intézet és Múzeum, Hadtörténelmi Levéltár és Irattár, Hadtörténelmi Levéltár. Institute and Museum of Military History of the MoD." ORCID: 0000-0002-3412-1770
} 
kezeslábas volt rendszeresítve, a fejvédő is hasonló anyagból készült.

Mivel a Honvédelmi Minisztérium iratanyaga nagyrészt megsemmisült, az ugróruha, az ugró-fejvédő és az ugrócipő bemutatása a rendelkezésre álló iratanyag alapján kerül sorra.

A 1939M nyári ugró-fejvédőből első körben 2 darabot az ugróruha készlethez szükséges hitelesített minta céljára kellett beszereznie a M. Kir. Honvéd Központi Ruhatárnak ${ }^{6}$, a HM 2/r osztály engedélye alapján, Ottenreiter Károly cé-

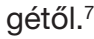

A nyári ugró-fejvédő rendszeresítése mellett, 1941 során más típusú fejvédő beszerzésére is sor került. A fül-részbe beépített fülhallgató nélküli bőr fejvédőből (pilótasapka) 1050 darabot rendeltek meg az ejtőernyős csapatok részére, amelyek leszállítását a megrendeléstől számított (1941. december) 3-4 hét múlva ígérték. ${ }^{8}$

Utóbbi adat alapján feltételezhető, hogy a legyártott 1939M ugró-fejvédők darabszáma nem lehetett elegendő, ezért volt szüksége a zászlóaljjá kibővült ejtőernyős századnak más típusú fejvédőre.

\section{Az 1939M (NYÁRI) UGRó-FEJVÉdő LEíRÁSA}

„A nyári fejvédő négy részből van összeállítva, melyek közül két rész a tetőt képezi, míg a másik kettő az oldalakat. $^{9}$

\section{Leírása}

A tetőt, valamint az oldalakat képező részek összevarrva, a varrások széthajtva és letǔzve vannak úgy, hogy a fejvédő középvarrásánál kb. $43 \mathrm{~cm}$, az oldalrészek összevarrásánál - a fej alakjának megfelelöen - kb. $36 \mathrm{~cm}$ hosszú. A homlokot, fejtetőt és tarkót védő tetörész együttes szélessége a homloknál kb. $11 \mathrm{~cm}$, a fejtetőn $\mathrm{kb} .14 \mathrm{~cm}$ és a tarkónál $\mathrm{kb}$. $9,5 \mathrm{~cm}$.

Az oldalrészek a fül elhelyezésének megfelelöen, valamint a fejvédőnek a fej kerekdedségének formája céljából kb. $6 \mathrm{~cm}$ hosszú bevágással vannak ellátva. E bevágások öszszevarrva, a varrások visszahajtva és letüzve vannak.

Az oldalrészek, és pedig a jobb oldali, a tetörésznél való összevarrás legnagyobb magasságától számítva kb. $35 \mathrm{~cm}$ hosszú, míg a baloldali rész kb. $24 \mathrm{~cm}$ hosszúságú nyelvben végződik. A fejvédő rögzítése céljából a jobboldali nyelvalakú rész alsó szélétöl kb. $9 \mathrm{~cm}$ magasságban felerösített 18 × $8 \mathrm{~mm}$ belméretü tövis nélküli égetett rézcsatban szabályozhatóan beillesztett kb. $18 \mathrm{~cm}$ hosszú, 1,8 cm széles és $\mathrm{kb} .2 \mathrm{~mm}$ vastag gumiszalag szolgál, melynek alsó végén egy $1 \mathrm{~mm}$ vastag és $16 \mathrm{~mm}$ átméröjü rézkarika van elhelyezve, míg a baloldali nyelv alakú rész végére egy 22 × 10 $\mathrm{mm}$ méretü tövis nélküli görgős rézcsat keret van a varrások közé beerősítve.

A jobboldali részen, a gumiszalagot tartó rézcsattól felfelé kb. $5.5 \mathrm{~cm}$-re egy alátétre rávarrt, acéllemezböl készült himkapocs (akasztóhorog) van gépvarrással felerösítve, mely a gumiszalag végén lévő karika beakasztására szolgál.

A fejvédő középvarrásának hátsó részén, az alsó széltől kb. $2 \mathrm{~cm}$-re van felerösítve, a szemüveg tartására szolgáló kb. $8,5 \mathrm{~cm}$ hosszú, kb. $1,2 \mathrm{~cm}$ széles, géppel körültüzött börszíjacska, melynek felső szabadon lévő végén egy szürkésbarna nyomókapocs van elhelyezve.

A fejvédő egészében saját anyagával van bélelve.

A fejvédő varrásához 40/2x2 angol számozású pamut cérna használandó."

A pilóták által hordott kezeslábas - bár szükségszerűen megfelelt - nem az ejtőernyős gyakorlóugrásokhoz volt kialakítva. Emiatt szükség volt némi módosításra, hogy vise-

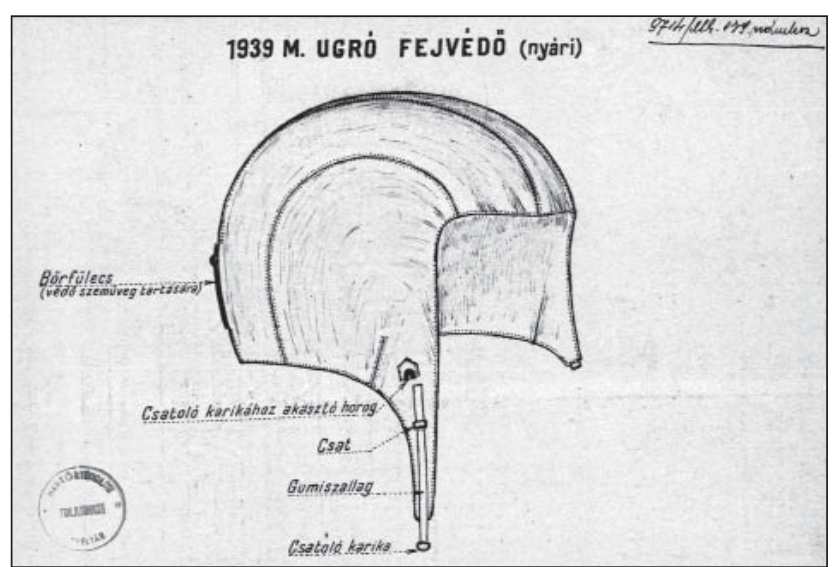

3. ábra. 1939M (nyári) ugró fejvédő rajza (HL I. B 31. d. 39. $445.440 / 2 /$ r. oszt. ált. -1940 .)

lése ne akadályozza az ugrást; ez lett a 39M egybeszabott ugróruha.

A Központi Ruhatár 1939. augusztus 12-én tájékoztatta a Honvédelmi Minisztérium 2/r. osztályát, hogy a beszerzendő 240 db ugróruha elkészítéséhez, darabonkénti 5 m-es anyaghányadot figyelembe véve, kb. 1200 m szövet kellett volna a felterjesztett l. jelzésű anyagminta szerinti szövetből. ${ }^{10}$

Ebből a külföldi eredetű anyagból nem lehetett a hazai kereskedelemben beszerezni ilyen nagy mennyiséget, ezért a javaslat szerint a II. jelzésű, sátorlap-esőgallér

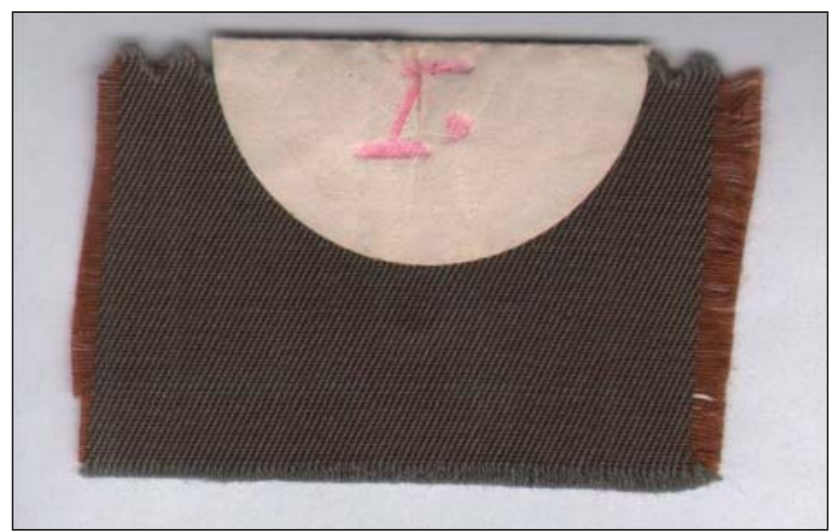

4. ábra. Az iratokban megnevezett I. jelzésú anyagminta (HL I. B 31. d. 39. 445.440/2/r. oszt. ált. - 1940.)

5. ábra. 1938M Sátorlap-esőgallér és szürke sávoly munkásruha múszaki leírása (HL I. B 31. d. 39. 445.440/2/r. oszt. ált. - 1940.)

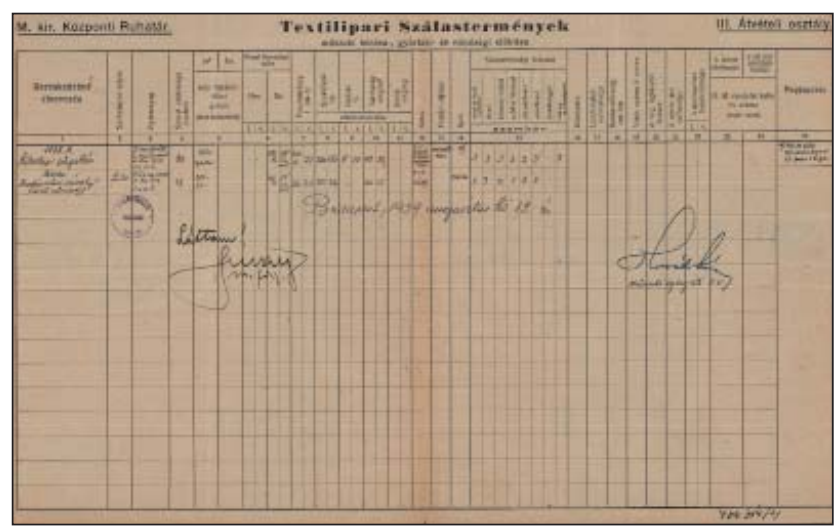


szövett, vagy a III. jelzéssel ellátott, L 30 fél-lensávoly szövetet kellett volna felhasználni. Az anyag kiválasztása sürgető volt, mivel a műszaki leírásnál tekintetbe kellett venni az anyag minőségi és müszaki követelményeit.

A sátorlap-esőgallér szövetanyaga a folyamatban lévő sátorlap-esőgallér konfekciójából, az egyes gyárak által leszállítandó 150-200 m szövetanyaggal a szükséglet biztosítható lett volna.

A HM 2/r. osztály augusztus 26-án az ejtőernyős század parancsnokságnak „sürgős!” jelzéssel küldött tájékoztatásában közölte, hogy a központi ruhatár jelentése szerint a sátorlap-esőgallér szövete megfelel a gyártás és használat céljára, mivel elég sűrű, nagy a szilárdsága, vízhatlanítva van és alapszínében (vagy más színben) is készülhet, utóbbit azonban nem ajánlották

Gyakorlati kipróbálásra nem adtak próbadarabot; a minisztériumi osztály véleménye szerint a sátorlap-esőgallér és szerelőruha a szombathelyi helyőrség valamelyik alakulatánál megtekinthető és kölcsönképp igénybe vehető.

1939. szeptember 5-én vitéz Bertalan Árpád százados a HM 2/r. osztálynak küldött tájékoztatása szerint az ugróruhát nem tudta csapatpróba alá venni, mivel a helyőrségben nem voltak ellátva az alakulatok ilyen ruhával. Sürgősen kérte egy mintapéldány elkészítését, mert ki kellett próbálni, hogy az emberi test kigőzölgését a II. számú anyag átereszti-e, valamint, hogy nem törik-e könnyen az erősebb érintkezési felületeken.

Amennyiben nem volt lehetséges az I. számú anyag beszerzése, úgy az áteresztőképesség és anyagszilárdság figyelembevételével a II. számú mintából kérte az ugróruhák elkészítését. A II. számú minta anyagából, egy színben kérte a megrendelést, az I. számú minta színében, ugyanis ilyen a külföldi repülőruhák színe, ha ez nem lehetséges, akkor egy színben (pl. zöld) lenne érdemes elkészíteni.

1939. szeptember 14-én az osztálynál megjelent az ejtőernyős század parancsnoka (vitéz Bertalan Árpád százados) és szóban előadta, hogy a javasolt sátorlap-esőgallér szövet a célnak előreláthatólag megfelelt, azt azonban légáteresztő képességére vonatkozólag gyakorlatban ki szerette volna próbálni. Bertalan százados előadta, hogy lehetőség szerint az ugróruha olyan festéssel készüljön el, mint a mintaruha külföldi anyagának színe.

A központi ruhatárnak, gyakorlati kipróbálás céljára 2 darab 1939M egybeszabott ugróruhát kellett elkészíteni, szőrmebélés és fejvédő nélkül. Az egyik ugróruhának az 1938M sátorlap-esőgallér rendszeresített fél-len szövetéből (szőrmebélés nélkül), a másiknak a háborús pamutszövetből kellett készülnie.

A rendszeresített sátorlap-esőgallér szövetanyaga fél-len (pamut és len), a háborús sátorlap szövetanyaga pedig tiszta pamut. Utóbbi anyaga kevésbé tört meg - ettől tartott az ejtőernyős század a beadványban.

A tiszta pamutból készült sátorlap mintapéldányát a Budakalászi Textilművek Rt. ${ }^{11}$ készítette. A gyár közlése szerint a kérdéses szövetből még kb. 6 m-nyi áruja volt, azonban már leplező festéssel elkészítve. A központi ruhatár tervezte egy ugróruha legyártását ebből a szövettípusból is. ${ }^{12}$

„[...] Az ugróruha e kísérleti példányai most a leplező szinezéssel ellátott szövetből készülhetnek, ugróruha céljaira történő rendszeresitése esetén azonban lehetöleg az eredeti mintaruha szinébe és csak ha ez elhárithatatlan akadályokba ütközne, a sátorlap-esőgallér zöld leplezó szinébe készüljön."13

Az ugróruhá(ka)t legyártásuk után le kellett szállíttatni a $\mathrm{m}$. kir. honvéd ejtőernyős századparancsnokság részére, Szombathelyre. Az ugróruha gyakorlati kipróbálásának eredményét mielőbb jelenteni kellett a HM 2/r. osztálynak, a kísérleti ugróruhákat pedig a központi ruhatárnak kellett visszaszállítani. A központi ruhatár a rendelkezésre bocsátott mintacikkek alapján elkészítette az ejtőernyős ugróruha és fejvédő műszaki leírását (ezt 1939. augusztus 23-án terjesztette fel), amelyeken változtatásokat hajtott végre.

A felterjesztett ugróruha műszaki leírása és a kiviteli minta között végrehajtott módosítások az ugróruha tartósságát fokozták és célszerűségét szolgálták.

A zsebeket $2 \mathrm{~cm}$-rel megnagyobbították, a szövethuzat lábszárain a felhajtás $1,5 \mathrm{~cm}$ helyett $3 \mathrm{~cm}$ lett, a szőrme szegélyezése változott, a szőrmén lévő gomblyukakat kikötötték, a szőrmén elhelyezett gombokat alátéttel erősítették fel.

Az ugróruha szövetének minőségére a központi ruhatár javaslatot tett, amelyet az ejtőernyős századparancsnokságnak véleményezésre kiadtak. Az ugróruha műszaki leírása a rendelkezésre bocsátott mintadarab után, annak megfelelően készült el, ezért a központi ruhatár véleménye szerint a Honvédelmi Minisztérium 2/r osztálynak jóvá kellett volna hagynia az elkészült kisebb változtatásokat. ${ }^{14}$

A központi ruhatár a Honvédelmi Minisztérium 2/r. osztályának 1939. október 5-én kelt feliratában jelentette, hogy a Wiva Sportárukereskedelmi Kft.-nél $1 \mathrm{db}$ fél-len anyagból (70,59 pengő) $1 \mathrm{db}$ háborús pamutanyagból (67,87 pengő), összesen 138,46 pengő értékben beszerzett 2 db 1939M egybeszabott ugróruhát és azt a m. kir. honvéd ejtőernyős század részére, Szombathelyre kiszállította. ${ }^{16}$

\section{6. ábra. 1939M egybeszabott ugróruha minőségi előírása} (HL I. B 31. d. 39. 445.440/2/r. oszt. ált. - 1940.)

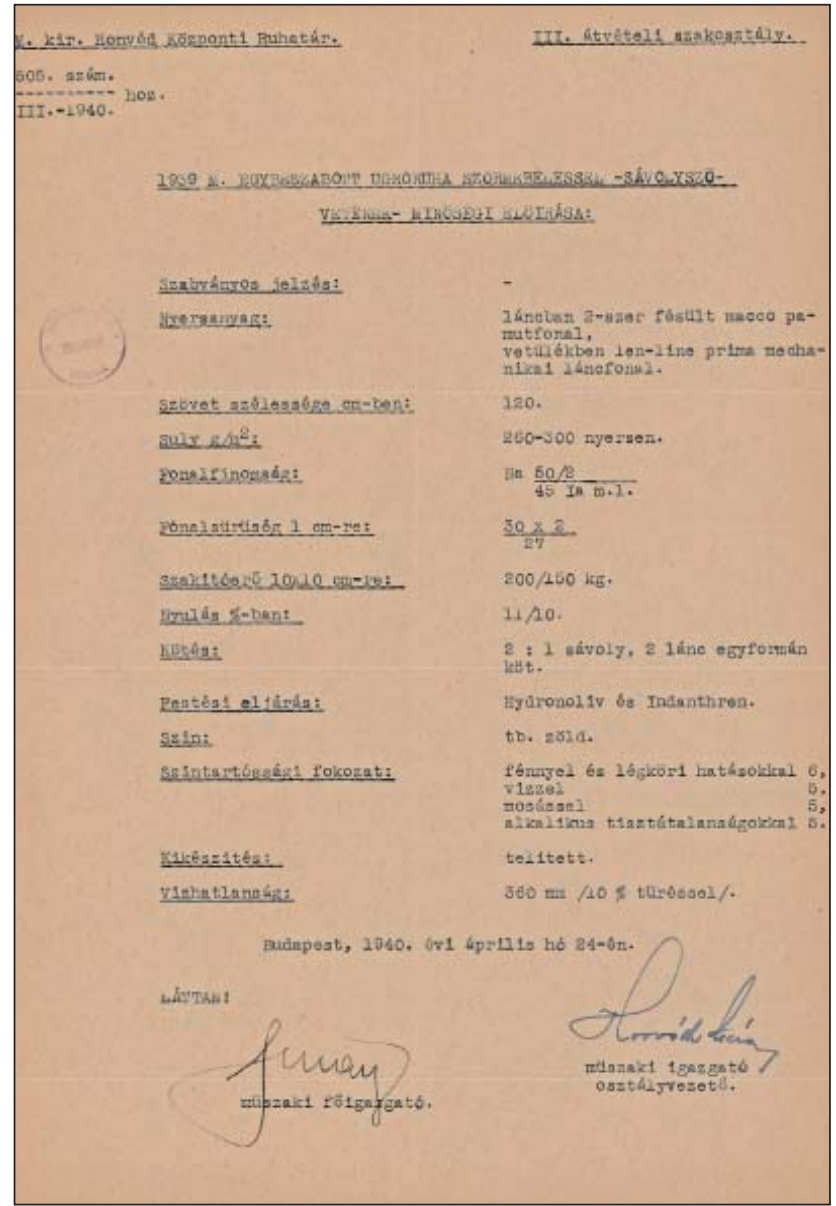




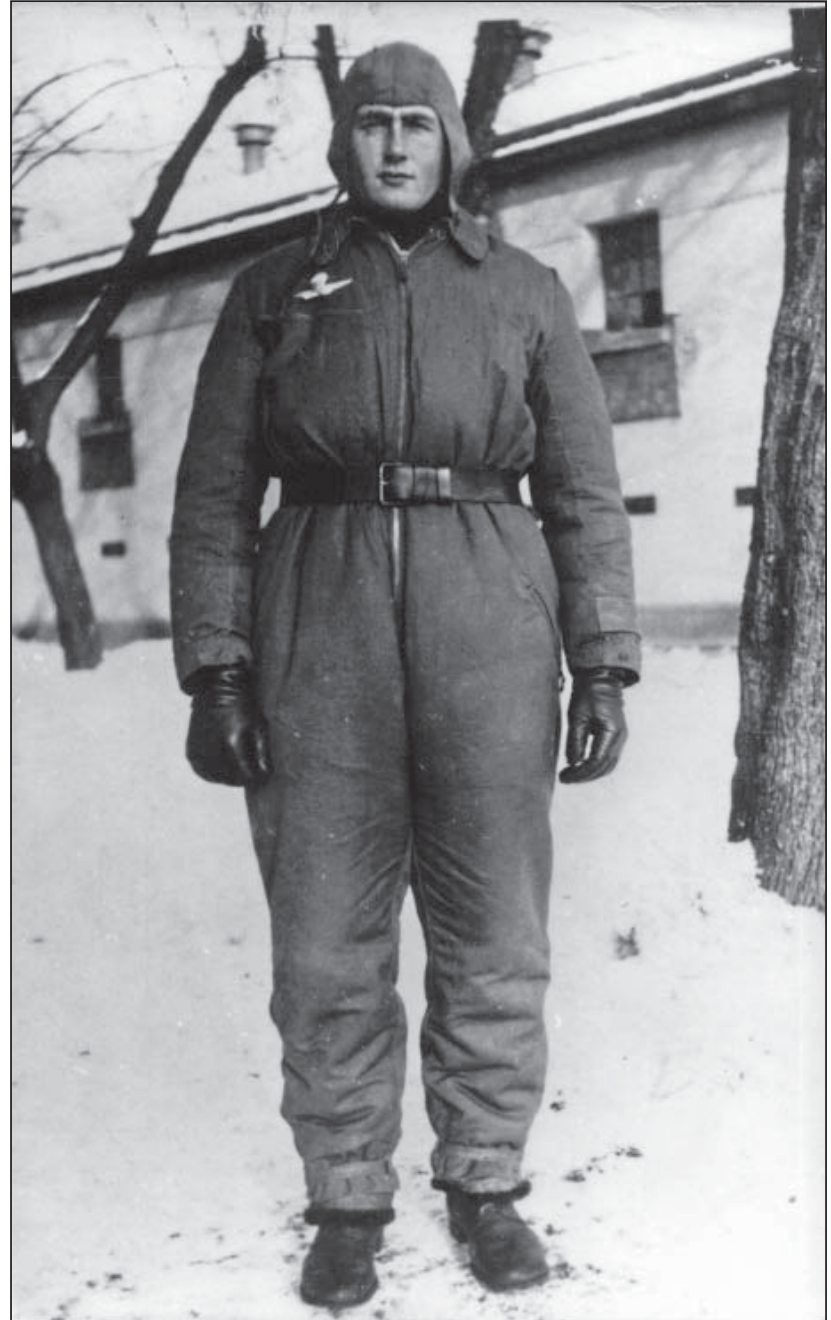

7. ábra. Téli ugrások alkalmával az egybeszabott ugróruhát báránybőr béléssel együtt viselték (Huszár János gyưjteménye)

A m. kir. honvéd ejtőernyős század jelentette, hogy az 1939. október 12-én leszálított 2 db egybeszabott ugróruhát kipróbálták. A sátorlap-esőgallér szövete a célnak megfelelt. A leplező színezés helyett kérték az eredeti mintaruha színéből elkészíteni a ruhákat. A nadrágzseb tájékon, az eddigi két felső zseben kívül, még két cipzárral ellátott ferde nyílású zseb elkészíttetését kérte, valamint azt, hogy az ugróruha ujj- és alsó lábszár végződése gumival zárható (összeszorítható) legyen. ${ }^{17}$

A központi ruhatár a Honvédelmi Minisztérium 2/r. osztályának 1939. november 9-én kelt jelentésében tájékoztatott az ugróruha kipróbálásáról. A próba eredményeként az ugróruha elkészítéséhez a fél-len sátorlap-esőgallér anyaga, halványzöld színre festve, megfelelőnek bizonyult. Az ejtőernyős század átirata szerinti módosításokkal a központi ruhatár egyetértett, amely szerint az alsó két zsebet feljebb kellett helyezni rézsút irányban, az ujjakon szélvédőket alkalmazni és övet rendszeresíteni. A központi ruhatár ugyanakkor nem javasolta az ugróruha lábszárain a szélvédők alkalmazását, ugyanis az ugrócipőket emiatt nem lehetne átbújtatni a lábszárakon, ráadásul a lábszárak alsó végein lévő bokaszorítók a célnak megfeleltek. ${ }^{18}$

A minta ugróruhákat a központi ruhatár a Viva Sport Árukereskedelmi Kft.-vel ${ }^{19}$ készíttette el, 70,59 pengő darabáron. A beszerzési árhoz hozzá jött még a nyári ugró-

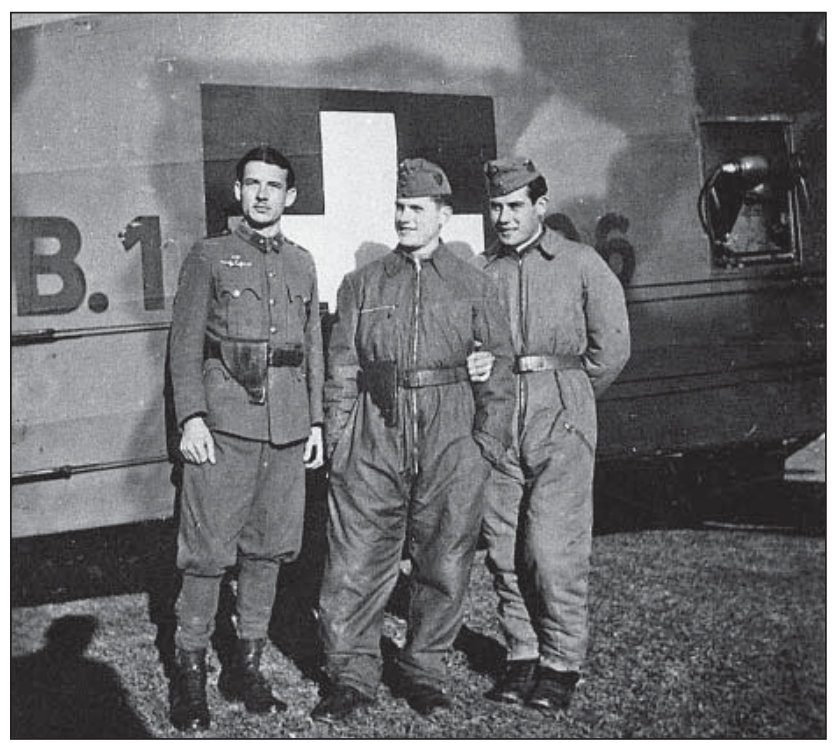

8. ábra. Ejtőernyős honvédek Ca.101-es szállítógép előtt (Huszár János gyứjteménye)

fejvédő költsége is, amelyet az osztály kb. 10 pengőre becsült. ${ }^{20}$

A 240 darab $^{21}$ ugróruha ára 90 pengővel számolva 21600 pengőbe került. Felszerelés (ugróruha) beszerzésére 43200 pengőnyi összeg volt előirányozva.

A központi ruhatárnak - a Honvédelmi Minisztérium 2/r. osztály utasításának megfelelően - zártkörű versenytárgyalást kellett kiírnia a 240 db 1939M egybeszabott ugróruha és a 240 db 1939M (nyári) ugró-fejfedő beszerzésére. Az ugróruhának az eredeti mintaruha színében kellett volna készülnie, ha ez „elháríthatatlan akadályokba ütközne”, akkor a sátorlap-esőgallér zöld leplező színében lehetett volna legyártani. A szállítás határideje 1940. február 29. volt.

A Honvédelmi Minisztérium 2/r. osztálya - HM 518180/2.r.-1939. szám alatt ${ }^{22}-240$ db ugróruhát rendelt meg a Kisipari Munkaszerző Szövetkezettől, kellékekkel együtt, 12,28 pengős ${ }^{23}$ egységáron. ${ }^{24} \mathrm{~A}$ megrendelt darabszám helyett a cég 4 darabbal többet készített el, ugyanis az előzetes ruhatári bevizsgálásra beküldött 4 darab ugróruhán kívül, aközben előírás módosítás miatt, újabb 4 darabot kellett bemutatni. Ezeken felül még az új előírás szerint az eredetileg megrendelt 240 db ruhát szállították le.

A HM 2/r osztály a szövetkezet által felajánlott 4 db ugróruha átvételét azzal a feltétellel engedélyezte, hogy a felajánlott mennyiségből $2 \mathrm{db}$-nak béléssel együtt, mintadarabként a mintacikkek leltárába kellett kerülnie. Az átvétel előtt a központi ruhatár javaslatát is kikérték.

A központi ruhatár válaszában jelezte, hogy a felhasználásra átadott vászonanyag a ruhatártól származott. $A$ cég - a központi ruhatár feltevése szerint - azért tudott 4 dbbal többet gyártani a kérdéses darabból, mivel ilyen típusú cikk első konfekcionálása miatt az anyaghányadot csak körülbelül tudták megállapítani, és az anyagot is körülbelüli mennyiségben tudták kiadni.

A 4 darab többletruhát pótmegrendelésként tervezték átvenni, méghozzá úgy hogy ebből $2 \mathrm{db}$ az ejtőernyős század részére kerülne átadásra, $2 \mathrm{db}$-ot pedig hiteles mintaként használnának fel.

A $2 / r$ osztály egyetértett a központi ruhatár fentebb említett javaslatával és elrendelte a 4 db ugróruha kézi bevásárlás útján történő beszerzését. ${ }^{25}$ 


\section{Az 1939M EgYBESZABOTt UGRóRUHA LEíRÁSA}

\section{„Anyaga}

A bélés barna színüre festett és molykár ellen védő anyaggal telített (eulánozott) nutriette juhbőr (Scherling) vagy báránybör.

Összeállítása

Az egybeszabott ugróruha két elülső és két hátsórészből, 2-2 ujjarészből és a gallérból áll. Az elörész valamint a hátrész egy darabból van szabva.

Az elörészt képező részek a hátrészekkel a hátközépen és a hónaljtól függőleges irányban vannak összevarrva. A mellrész közepén lévő nyilás egy kb. $75 \mathrm{~cm}$ hosszú és becsukott állapotban $7 \mathrm{~mm}$ széles villámzárral csukódik, illetve nyitódik. A villámzár a mell középrészén a gallér felső szélétől kb. az ágazatig terjed.

A villámzár az elörészekre olyképen van felvarrva, hogy becsukott állapotban $7 \mathrm{~mm}$ széles villámzárat az eleje szélei takarják.

A jobboldali mellrészen egy kb. $18 \mathrm{~cm}$ széles és $\mathrm{kb} .17 \mathrm{~cm}$ mély saját anyagából készült rátüzött és kb. $15 \mathrm{~cm}$ hosszú villámzárral ellátott zseb van alkalmazva.

Az ugróruha elülső lábszárain a nadrágzseb magasságában rézsútosan vágott egy-egy kb. $20 \mathrm{~cm}$ széles és kb. 22 $\mathrm{cm}$ mély becsukott állapotban $\mathrm{kb} .7 \mathrm{~m} / \mathrm{m}$ széles villámzárral ellátott zseb van. ${ }^{26}$ tó.

Az egybeszabott ugróruha lépésben az ágazatnál toldha-

A hátrész és a külső oldalvarrások, valamint az ujjak külső varrásai úgynevezett áttüzött varrással készítendők. Az ugróruha egy-egy elülső és egy-egy hátsó lábszárakban végződő részből olyképen van összeállitva, hogy a külső oldalvarrások áttüzve, míg a belső varrások egyszerü varrással készülnek.
A lábszárak külső varrásaiban egy-egy az alsó széltől kb. $40 \mathrm{~cm}$ magasságig $7 \mathrm{~mm}$ széles villámzárral ellátott lábikra bebújó nyilás van.

A lábszárak alsó végein az alsó széltől $\mathrm{kb} .5 \mathrm{~cm}$ magasságban egy-egy $2 \mathrm{~cm}$ széles és kb. $50 \mathrm{~cm}$ hosszú kétrétüen összetüzött, betétvászonnal ellátott, szélein letüzött saját anyagból készült bokaszorító van három csukor segítségével alkalmazva. A bokaszorító szallagok egyik vége ék alakban végződik, a másik vége pedig 2 drb. $2.5 \mathrm{~cm}$ széles tövis nélküli fémcsattal van ellátva. A bokaszoritókat tartó 3 csukor közül az elülső lábszáron egy-egy darab van.

A lábszárak alsó szélei kb. $3 \mathrm{~cm}$ szélességben felhajtva és letüzve készülnek.

Az ujjak két-két darabból vannak szabva. Az ujjak belsó összevarrásai közé az alsó széltöl kb. $8 \mathrm{~cm}$ magasságban egy-egy kb. $14 \mathrm{~cm}$ hosszú és $\mathrm{kb} .4 .5 \mathrm{~cm}$ széles gomblyukkal ellátott szorítószallag van erōsítve. Az alsó és felső ujjakon a szorítószallagnak megfelelően 3-3 drb. kb. $2 \mathrm{~cm}$ átmérőjü kődió gomb van alkalmazva.

Az ujjak alsó végei kb. $3.5 \mathrm{~cm}$ szélességben felhajtva és letüzve készülnek.

Az ujjak alsó végei 1-1 saját anyagából készült kb. $8 \mathrm{~cm}$ széles szélfogóval vannak ellátva. A szélfogóba tartós nyers gummiszalag füzendő.

Az egybeszabott ugróruhának a derékban való megszoritására egy kb. 140-150 cm hosszu és $\mathrm{kb} .3 .5 \mathrm{~cm}$ széles kétrétüen összetüzött saját anyagából készült öv szolgál, mely öv közé egy hosszirányban vágott $\mathrm{kb} .3 \mathrm{~cm}$ széles betétvászon van bevarrva. Az öv csatlékos vége mérsékelten hegyezett, a csattos vége pedig az öv szabályozására $2 \mathrm{db} \mathrm{kb} .3 \mathrm{~m} / \mathrm{m}$ falvastagságú és $\mathrm{kb}$. $31 / 2 \mathrm{~cm}$ átmérőjü nikkelezett vaskarikával van ellátva.

(Folytatjuk)

\section{JEGYZETEK}

1 Köszönetem Varga Imrének, a Károli Gáspár Református Egyetem Történelemtudományi Doktori Iskola doktoranduszának, hogy felhívta figyelmem ezekre az értékes iratokra.

2 Reszegi Zsolt: Légi huszárok. Pápai Levéltár, Pápa, 2013. 83.

3 Vitéz Bertalan Árpádon kívül Kiss Zoltán (balról a második) és vitéz Makray Ferenc (jobbról a legszélső) hadnagyok azonosíthatók be egyértelműen. Gáll Gábor, a Magyar Ejtőernyősök Bajtársi Szövetsége Kegyeleti Bizottságának elnöke, ejtőernyős kutató szerint a következő sorrendben láthatók a tisztek a szombathelyi repülőtéren készített fényképen: Pataky Géza, Kiss Zoltán, Bertalan Árpád

Tassonyi Edömér, Majthényi Imre, Makray Ferenc. Ezúton köszönöm Gáll Gábornak a segítséget.

4 Tóth László (szerk.): A Magyar Királyi Honvédség egyenruhái. Budapest. Huniform Kiadó, 2007, 30. old. Bővebben lásd: Baczoni Tamás - Hadnagy Róbert: Repülőgép-vezető nyári hajózóruhában 1942-1943. http://www.hadakutjan.hu/egyenruhak_repulogep_ vezeto.php. Letöltés ideje: 2016. 04. 08. 17:10.

5 A kép eredeti aláirása: „A repülő műszaki század katonái munka közben”. Első közlés: Huszár János „Honvéd ejtőernyősök Pápán 1939-1945. Pápa, 1993. A Jókai Kör kiadványa (oldalszám nélkül). 6 A továbbiakban: Központi Ruhatár.

7 Hadtörténelmi Levéltár I. B 31. d. 39. 443.625/2/r. oszt. ált. - 1940. (a továbbiakban: $\mathrm{HL}$ )

8 HL I. B 31. d. 39. 78100/2/r. oszt. eln. -1941.

$9 \mathrm{~A}$ fejvédők belső-felső részét átvételi és méretnagyság bélyegzővel látták el.

10 HL I. B 31. d. 39. 445.440/2/r. oszt. ált. - 1940.

11 Teljes nevén Budakalászi Textilművek Klinger Henrik Rt. 1923-ban alapították, székháza az V. kerületben, a Wekerle Sándor u. 11. szám alatt állt. A gyártelep Budakalászon, a Szentendrei úton volt. Nagy Magyar Compass 1939 - 1940/II. rész: Iparvállalatok. Szerk.: Dr.
Galánthai Nagy Sándor. Pátria Nyomda, Budapest 337. old. (a továbbiakban: Nagy Magyar Compass)

12 A 2 db ugróruha költségkihatása összesen 80 pengőt tett ki. HL I. B 31. d. 39. 445.440/2/r. oszt. ált. -1940.

13 HL I. B 31. d. 39. 445.440/2/r. oszt. ált. - 1940.

14 HL I. B 31. d. 39. 445.440/2/r. oszt. ált. - 1940.

15 Wiva Sportárukereskedelmi Kft.: Előbb Sportárukereskedelmi Kft. 1932-ben alapították. Címe: IV. kerület, Váci u. 9. További adatokért lásd: Nagy Magyar Compass 1942-1943./II. rész, 695. old

16 HL I. B 31. d. 39. 445.440/2/r. oszt. ált. - 1940.

17 HL I. B 31. d. 39. 445.440/2/r. oszt. ált. -1940.

18 HL I. B 31. d. 39. 445.440/2/r. oszt. ált. -1940.

19 Teljes nevén „Wiva” Sportáru Kereskedelmi Kft., ahogy a HL I. B 31. d. 39.443.625/2/r. oszt. ált. - 1940. jelzetű iratban említették.

20 HL I. B 31. d. 39. 445.440/2/r. oszt. ált. - 1940.

$21 \mathrm{Az}$ irat pro domo részében $200 \mathrm{db}$ ugróruhát említenek. Ez elírás lehet, mivel a becsült költségek 21600 pengőt tettek ki (darabonkénti 90 pengős árral), ami 200 darab esetén csak 18000 pengő lett volna. HL I. B 31. d. 39. 445.440/2/r. oszt. ált. - 1940.

22 Sajnos az irat a tanulmány elkészítésekor nem volt fellelhető

23 A 4 darab ugróruha ára 94,12 pengőt (12,28 pengős darabár), a 4 darab szőrmebélésé 383,92 pengőt (95,98 pengős darabár), a 2 darab ugró fejvédő ára 11, 20 pengőt tett ki (5,60 pengős darabár).

24 A Kisipari Munkaszerző Szövetkezet korabeli címe: V. kerület, Zrínyi utca 7.

25 HL I. B 31. d. 39. 443.625/2/r. oszt. ált. - 1940.

26 Kiegészítés a HL I. B 31. d. 39. 503.758/2/r. - 1939. jelzetű irat 2. számú mellékletéből, mely már a végleges változtatásokat tartalmazza (a HL I. B 31. d. 39. 445.440/2/r. - 1940. alapszámú irathoz szerelve) 